\title{
Kinetic modeling and simulation of bio-methanol process from biogas by using aspen plus
}

\author{
Rujiroj Tamnitra ${ }^{1,}$, Rujira Jitwung ${ }^{2}$, Tarawipa Puangpetch ${ }^{1}$, Weerawat Patthaveekongka ${ }^{1}$, and Kamonrat Leeheng $^{2}$ \\ ${ }^{1}$ Chemical Engineering Department, Faculty of Engineering and Industrial Technology, Silpakorn University, Nakorn pathom, Thailand \\ ${ }^{2}$ Expert Center of Innovative Clean Energy and Environment, Thailand Institute of Scientific and Technological Research (TISTR), \\ KhongLuang Patumthani Thailand
}

\begin{abstract}
A process of bio-methanol from biogas was studied by modifying kinetic model of reaction's Richardson and Paripatyadar comparing with laboratory data. Bio-methanol process consists of 2 steps: reforming reaction (at atmospheric pressure, temperature $500-750{ }^{\circ} \mathrm{C}$ ) and methanol synthesis (at constant pressure 40 bar, temperature $140-280^{\circ} \mathrm{C}$ ). The reaction model of each step was individual simulated. Next both steps were integrated, then they were simulated using ASPEN PLUS software. This work investigated the optimum operating condition and predicted result of both reactions. The developing model was obtained, then it was applied for ten thousand liters per day of methanol. The simulation result received from reforming reaction showed increasing temperature effect to rising in $\mathrm{CH}_{4}$ and $\mathrm{CO}_{2}$ conversion and relating with laboratory result. The optimum condition of methanol synthesis is temperature $200{ }^{\circ} \mathrm{C}$ under constant pressure 40 bar.
\end{abstract}

\section{INTRODUCTION}

In most industry, the main target requires in increasing productivity and low operating cost. The modification or remodel of process is hardly adjusted without enough supporting data. The process simulation is one of alternative tools which it is useful to predict process and to support major result before the process is modified. The two main cases of simulation are i) an innovative process: studying variable parameters or condition effecting to process for prediction and comparison with alternative process and design process. ii) a conventional process: obtaining behaviour and mechanism of process. The advantages of simulation are not only saving cost, time and life but also providing fast and reliable result. For example, this tool can be applied for testing a critical condition (high pressure, high temperature, and limitation of chemical).[1]

Nowadays, renewable energy is interested for substituting fossil fuels such as coal, petroleum and etc. Biogas can be produced from manure, food, waste, and tapioca starch or sugarcane residue. Biogas process is a practical process to eliminate massive waste water from industries. Biogas contains mainly methane and carbon dioxide. Therefore, it is used as an alternative fuel for electricity generation. Only methane in biogas is combusted for producing electricity. However, carbon dioxide is wasted to environment. To subsidize biogas production, $\mathrm{CO}_{2}$ utilization has been studied by many researchers. An attractive research is using $\mathrm{CO}_{2}$ for biomethanol production. The bio-methanol can be supplied as a raw material in biodiesel process. In addition, methanol requirement in Thailand was imported more than 500 million liters per year (data form department of industrial works, 2017). As a result, the production of bio-methanol is interested not only solving $\mathrm{CO}_{2}$ problem form using biogas as an electricity but also alleviating amount of methanol importing from outside country.

Methanol production from biogas comprises of two main reactions: methane reforming and methanol synthesis. The methane reforming is a process which carbon dioxide and methane are reacted to form synthesis gas (syngas) consisted of carbon monoxide and hydrogen. For practical process water is added to the process. The methane reforming process consists of three main reactions: dry reforming of methane reaction (1), steam reforming of methane (2), and water gas shift reaction (3). The methanol synthesis occurs via three reactions: hydrogenation of carbon monoxide (4), hydrogenation of carbon dioxide (5), and water gas shift reaction (6).[2-4]

Methane Reforming

$\begin{array}{lll}\mathrm{CH}_{4}+\mathrm{CO}_{2} & \rightarrow & 2 \mathrm{CO}+2 \mathrm{H}_{2} \\ \mathrm{CH}_{4}+\mathrm{H}_{2} \mathrm{O} & \rightarrow & \mathrm{CO}+3 \mathrm{H}_{2} \\ \mathrm{CO}+\mathrm{H}_{2} \mathrm{O} & \rightarrow & \mathrm{CO}_{2}+2 \mathrm{H}_{2}\end{array}$

$\mathrm{CO}+\mathrm{H}_{2} \mathrm{O} \rightarrow$

$\mathrm{CO}+2 \mathrm{H}_{2} \rightarrow \mathrm{CH}_{3} \mathrm{OH}$

$\mathrm{CO}_{2}+3 \mathrm{H}_{2} \rightarrow \mathrm{CH}_{3} \mathrm{OH}+\mathrm{H}_{2} \mathrm{O}$

$\mathrm{CO}+\mathrm{H}_{2} \mathrm{O} \rightarrow \mathrm{CH}_{3} \mathrm{OH}+\mathrm{H}_{2} \mathrm{O}$

\footnotetext{
* Corresponding author: rujira_j@tistr.or.th
} 


\section{RESEARCH METHODOLOGY}

This research focuses on the design of biomethanol production process from biogas using process simulation by ASPEN PLUS software and applies for ten thousand liters per day capacity.

\subsection{Reaction modeling}

Reaction modeling can be divided in two reactions, including methane reforming reaction and methanol synthesis reaction. The previous work of kinetic studies was presented in this section and developed kinetic models by using laboratory operating condition.

Methane reforming reaction, the reaction model was first used by Richardson and Paripatyadar. The reaction rate equation was calculated using a LangmuirHinshelwood rate expression. This reaction was developed by Yacine Benguerba and Lila Dehimi adding a reverse reaction term in the previous model to explain the laboratory results. The developed kinetic reaction are shown in equation (7) and (8). [5, 6]

$$
\begin{aligned}
& r_{1}=\frac{\mathrm{k}_{1} \mathrm{~K}_{\mathrm{CO}_{2}, 1} \mathrm{~K}_{\mathrm{CH}_{4}, 1} \mathrm{P}_{\mathrm{CH}_{4}} \mathrm{P}_{\mathrm{CO}_{2}}}{\left(1+\mathrm{K}_{\mathrm{CO}_{2}, 1} \mathrm{P}_{\mathrm{CO}_{2}+}+\mathrm{K}_{\mathrm{CH}_{4}, 1} \mathrm{P}_{\mathrm{CH}_{4}}\right)^{2}}\left(1-\frac{\left(\mathrm{P}_{\mathrm{CO} \mathrm{P}_{2}}\right)^{2}}{\mathrm{~K}_{\mathrm{P}_{1}}\left(\mathrm{P}_{\mathrm{CH}_{4}} \mathrm{P}_{\mathrm{CO}_{2}}\right)}\right) \\
& r_{2}=\frac{\mathrm{k}_{2} \mathrm{~K}_{\mathrm{CO}_{2}, 2} \mathrm{~K}_{\mathrm{H}_{2}, 2} \mathrm{P}_{\mathrm{CO}_{2}} \mathrm{P}_{\mathrm{H}_{2}}}{\left(1+\mathrm{K}_{\mathrm{CO}_{2}, 2} \mathrm{P}_{\mathrm{CO}_{2}}+\mathrm{K}_{\mathrm{H}_{2}, 2} \mathrm{P}_{\mathrm{H}_{2}}\right)^{2}}\left(1-\frac{\left(\mathrm{P}_{\mathrm{CO} \mathrm{P}_{2} \mathrm{O}}\right)}{\mathrm{K}_{\mathrm{P}_{2}}\left(\mathrm{P}_{\mathrm{CO}_{2}} \mathrm{P}_{\mathrm{H}_{2}}\right)}\right)
\end{aligned}
$$

Methanol Synthesis Reaction, the kinetic was modeled and calculated using a Langmuir-Hinshelwood rate expression. This kinetic model of methanol synthesis is suitable in low pressure condition. However, it is limited in high pressure environment. Van den Bussche and Froment developed the model by adding equilibrium term to eliminate problem of high pressure condition. The model are shown in equation (9) and (10).

$$
\begin{gathered}
r_{\mathrm{MeOH}}=k_{\mathrm{MeOH}} \frac{\left(p_{\mathrm{CO}_{2}} p_{\mathrm{H}_{2}}\right)-\left(1 / K_{p \mathrm{MeOH}}\right)\left(p_{\mathrm{CH}_{3} \mathrm{OH}} p_{\mathrm{H}_{2} \mathrm{O}} / p_{\mathrm{H}_{2}^{2}}\right)}{\left(1+K_{\mathrm{a}}\left(p_{\mathrm{H}_{2} \mathrm{O}} / p_{\mathrm{H}_{2}}\right)+K_{\mathrm{b}} \sqrt{p_{\mathrm{H}_{2}}}+K_{\mathrm{c}} p_{\mathrm{H}_{2} \mathrm{O}}\right)^{3}} \\
r_{\mathrm{RWGS}}=k_{\mathrm{RWGS}} \frac{p_{\mathrm{CO}_{2}}-\left(1 / K_{p \mathrm{RWGS}}\right)\left(p_{\left.\mathrm{CO} p_{\mathrm{H}_{2} \mathrm{O}} / p_{\mathrm{H}_{2}}\right)}\right.}{\left(1+K_{\mathrm{a}}\left(p_{\mathrm{H}_{2} \mathrm{O}} / p_{\mathrm{H}_{2}}\right)+K_{\mathrm{b}} \sqrt{p_{\mathrm{H}_{2}}}+K_{\mathrm{c}} p_{\mathrm{H}_{2} \mathrm{O}}\right)}
\end{gathered}
$$

In this present work, the modification of some constant values of (9) and (10) are adjusted to meet with the laboratory result by using linear regression method. The operating conditions were used: temperature range $140-280{ }^{\circ} \mathrm{C}$ and pressure $40-45$ bar.[3, 7-9]

\subsection{Process simulation}

Many researchers attempt to acquire accurate modeling of the relevant kinetic processes because the kinetic modeling is a key of the methanol process indicating the behaviour of reactor. The expressions for reactor models are adapted from the work of Richardson et al. and Van den Bussche et al. Catalytic reaction in fixed-bed reactor was simulated in one dimensional heterogeneous model. Temperature and concentration gradients are accounted in axial direction. The flow diagram of the bio-methanol production process from biogas is shown in Fig. 1. ASPEN PLUS software is tool for this process simulation.

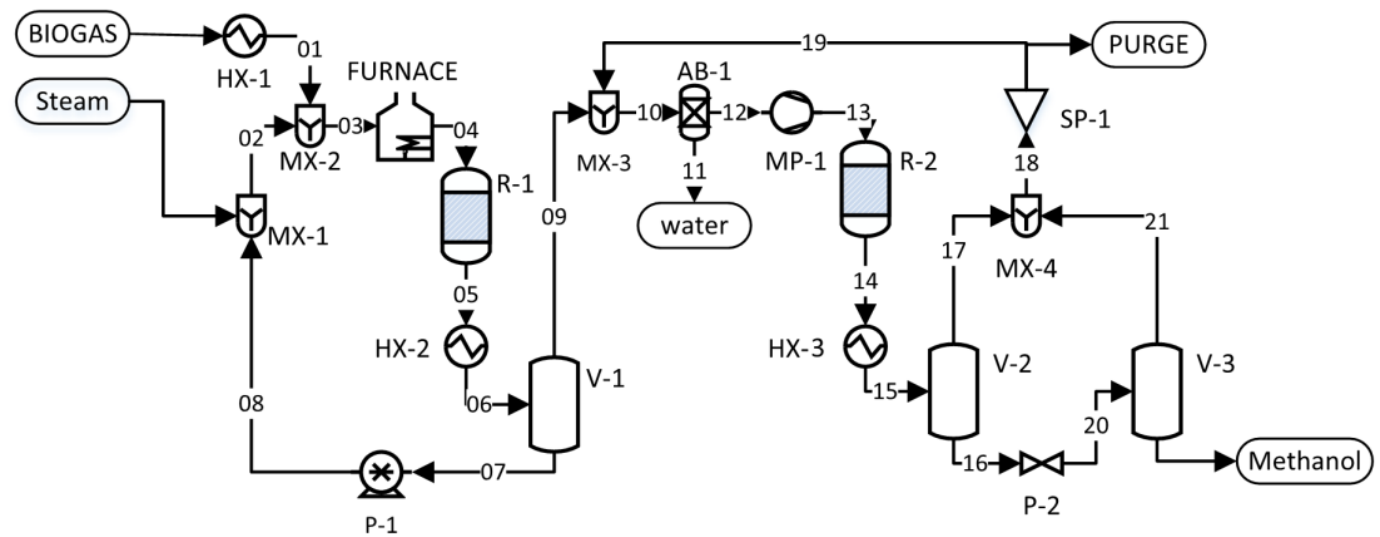

Fig. 1. Process flowsheet of methanol production

Biogas is preheated by low pressure steam (HX-1), mixed with steam in low pressure steam (HX-2) and then heated up in furnace to raise high temperature to meet up desired temperature in reactor (R-1). After reforming reaction, the fluid is cooled down in heat exchanger (HX-2) and trapped in vessel (V-1). The fluid is separated in two phases. Liquid is water which fed back by pump (P-1), mixing with steam in mixer (MX-1). Vapour or syngas was fed to absorption unit (AB-1) removing water before passing the syngas to next step. The methanol reaction is occurred in reactor (R-2) operating temperature $\left(140-180{ }^{\circ} \mathrm{C}\right)$. The methanol product and residue gas are cooled down to $40{ }^{\circ} \mathrm{C}$ by cooling water in heat exchanger (HX-3). The fluid contains two phases: vapour stream and liquid stream, methanol in liquid stream is firstly trapped in vessel (V2 ) then it depressurized to atmospheric pressure by relief valve (P-2) sending to vessel (V-3) for second trapped and finally obtaining methanol. The upper stream is residue gas passing and mixing with the vapour stream from vessel (V-2) in mixer (MX-4). This recycle gas is partially purged $(10 \%)$ and returned $(90 \%)$ to mixer (MX-3) for producing methanol production. 


\subsection{Experimental section}

The reforming reactor was made from 304 stainless steel with the length, inside diameter and outside diameter of $1.6 \mathrm{~cm}$. and $2.0 \mathrm{~cm}$, respectively. The flow of mixed gas was controlled by mass-flow controller and the methanol synthesis reactor was fixed-bed continuous flow reactor made from 304 stainless steel belonging dimension of $30 \mathrm{~cm}$ length and $1.6 \mathrm{~cm}$ inside diameter. $[10,11]$

\section{RESULT AND DISCUSSION}

\section{1 reactor model}

\subsubsection{Methane Reforming Reactor}

The results of modeling data were compared with laboratory data. The operating conditions were used by varying temperature range $500-750 \quad{ }^{\circ} \mathrm{C}$ under atmospheric pressure. In term of methane percentage conversion was shown in Fig. 2-3. The results were investigated that rising temperature effected to increasing methane conversion and relating to the developing model specification in high temperature range $\left(500-750{ }^{\circ} \mathrm{C}\right)$. The error percentage is in range of $5.7-21.6 \%$.

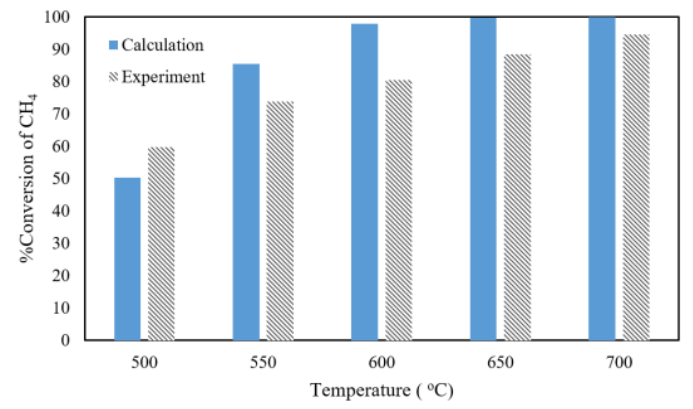

Fig. 2. Comparison of $\mathrm{CH}_{4}$ developing model with laboratory result.

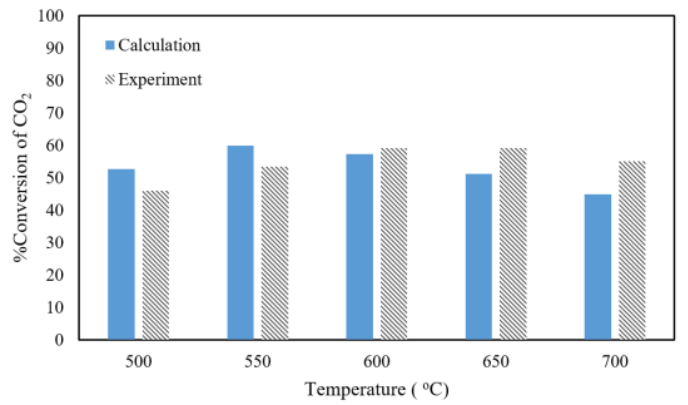

Fig. 3. Comparison of $\mathrm{CO}_{2}$ developing model with laboratory result.

The simulation results were shown that $\mathrm{CO}_{2}$ conversion was increased when increasing temperature in range of $500-600{ }^{\circ} \mathrm{C}$ and then it was decreased after temperature over $600{ }^{\circ} \mathrm{C}$. Comparing the developing model with laboratory, the error percentage is 3.1 $18.4 \%$ at $500-750{ }^{\circ} \mathrm{C}$. Meanwhile, $\mathrm{H}_{2} / \mathrm{CO}$ molar ratio was gradually increased when rising temperature. The percentage of $\mathrm{H}_{2} / \mathrm{CO}$ is deviated of $9.6-29 \%$.

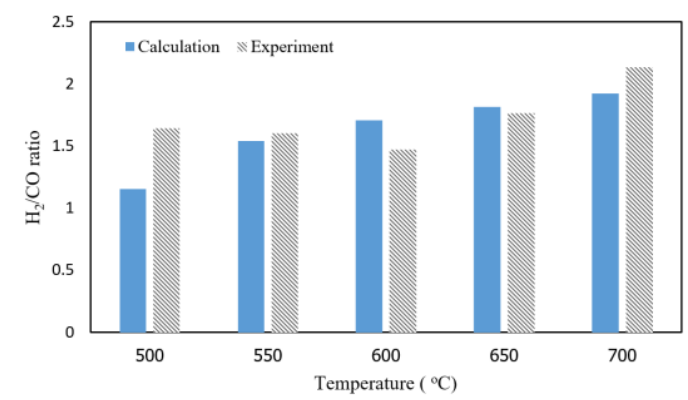

Fig. 4. Comparison of $\mathrm{H}_{2} / \mathrm{CO}$ ratio developing model and laboratory result.

\subsubsection{Methanol Synthesis Reaction}

The simulation and laboratory results of methanol synthesis were depicted in Fig. 5-6. The $\mathrm{CO}$ and $\mathrm{H}_{2}$ conversion generated from the reforming reaction are the main factor of methanol synthesis. The developing model is fitted with the $\mathrm{CO}$ and $\mathrm{H}_{2}$ conversion obtaining from laboratory in temperature above $200{ }^{\circ} \mathrm{C}$; however, it is widely differed under $200{ }^{\circ} \mathrm{C}\left(140-200{ }^{\circ} \mathrm{C}\right)$. This result can be explained that the developing model is out of the minimum range which the previous work $[5,12$, 13] used $\left(130-300^{\circ} \mathrm{C}\right)$. The optimum conversion of $\mathrm{CO}$ and $\mathrm{H}_{2}$ is temperature at $200{ }^{\circ} \mathrm{C}$ acquired from the developing simulation agreed with the laboratory.

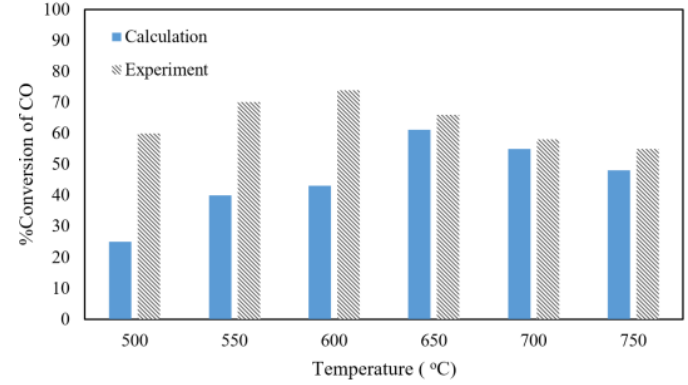

Fig. 5. Comparison of $\mathrm{CO}$ and $\mathrm{H}_{2}$ developing model with laboratory result.

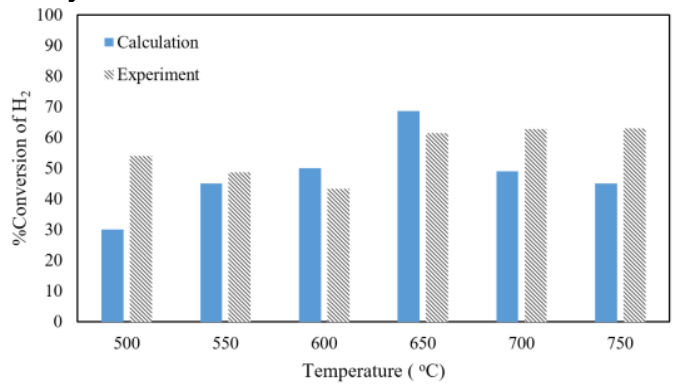

Fig. 6. Comparison of $\mathrm{CO}$ and $\mathrm{H}_{2}$ developing model with laboratory result.

\subsection{Process simulation}

The study of methanol simulation process was applied for ten thousand liters/day. The result was shown in terms of material balances, chemical compositions, temperatures and pressure streams in table 1 . It is found that 8483.65 liters $/ \mathrm{min}(343.29 \mathrm{~mol} / \mathrm{min})$ of biogas and $3062.5 \mathrm{~kg} / \mathrm{min}(170.00 \mathrm{~mol} / \mathrm{min})$ of water produce $10,000 \mathrm{liters} /$ day $(223.40 \mathrm{~mol} / \mathrm{min})$ of methanol. Some equipment units are installed to methanol process for specific reasons as following. Furnace was used for 
increasing temperature because reaction in reactor (R-1) is highly endothermic reaction that requires high heat source to increase $\mathrm{CH}_{4}$ conversion. After reactor (R-1), water dissolved in gas stream can effect to the catalyst activity in methanol synthesis and can react with carbon monoxide reducing reactant for methanol synthesis and also generating $\mathrm{CO}_{2}$ in the system as explained in equation (3). The vessel (V-1) and (V-2) were installed because the liquid methanol cannot be perfectly trapped in single stage and it is not liquefied under high pressure. The expansion valve $(\mathrm{P}-2)$ reduces the pressure of methanol stream to the atmosphere, then the liquid methanol is easily condensed into liquid phase.

Table 1. Stream summary of bio-methanol production using developing model in ASPEN PLUS

\section{CONCLUSION}

Methanol is an important chemical for downstream chemicals. The process simulation of methanol produced from biogas is tooled by ASPEN PLUS using the developing kinetic data shown that the conversion of $\mathrm{CH}_{4}, \mathrm{CO}_{2}$ and $\mathrm{H}_{2} / \mathrm{CO}$ ratio fitted in ranging of high temperature in both reactors. This work can apply for the optimum condition, scale up the process capacity and evaluate the feasibility economic.

\begin{tabular}{|c|c|c|c|c|c|c|c|c|c|}
\hline Stream & BIOGAS & STEAM & 1 & 2 & 3 & 4 & 5 & 6 & 7 \\
\hline Total Flow $\mathrm{mol} / \mathrm{min}$ & 343.29 & 170.00 & 343.29 & 301.13 & 644.42 & 644.42 & 1021.69 & 1021.69 & 131.13 \\
\hline Temperature $\mathrm{C}$ & 25.00 & 125.00 & 105.00 & 99.46 & 72.09 & 750.00 & 750.00 & 35.00 & 35.00 \\
\hline Pressure bar & 1 & 1 & 1 & 1 & 1 & 5 & 1 & 1 & 1 \\
\hline CH4 & $5.50 \mathrm{E}-01$ & $0.00 \mathrm{E}+00$ & $5.50 \mathrm{E}-01$ & $1.38 \mathrm{E}-06$ & $2.93 \mathrm{E}-01$ & $2.93 \mathrm{E}-01$ & $1.75 \mathrm{E}-04$ & $1.75 \mathrm{E}-04$ & $3.17 \mathrm{E}-06$ \\
\hline $\mathrm{CO} 2$ & $4.50 \mathrm{E}-01$ & $0.00 \mathrm{E}+00$ & $4.50 \mathrm{E}-01$ & $3.24 \mathrm{E}-03$ & $2.41 \mathrm{E}-01$ & $2.41 \mathrm{E}-01$ & $8.50 \mathrm{E}-02$ & $8.50 \mathrm{E}-02$ & $7.44 \mathrm{E}-03$ \\
\hline $\mathrm{CO}$ & $0.00 \mathrm{E}+00$ & $0.00 \mathrm{E}+00$ & $0.00 \mathrm{E}+00$ & $2.89 \mathrm{E}-04$ & $1.35 \mathrm{E}-04$ & $1.35 \mathrm{E}-04$ & $2.52 \mathrm{E}-01$ & $2.52 \mathrm{E}-01$ & $6.65 \mathrm{E}-04$ \\
\hline $\mathrm{H} 2$ & $0.00 \mathrm{E}+00$ & $0.00 \mathrm{E}+00$ & $0.00 \mathrm{E}+00$ & $9.17 \mathrm{E}-10$ & $4.29 \mathrm{E}-10$ & $4.29 \mathrm{E}-10$ & $4.87 \mathrm{E}-01$ & $4.87 \mathrm{E}-01$ & $2.11 \mathrm{E}-09$ \\
\hline $\mathrm{H} 2 \mathrm{O}$ & $0.00 \mathrm{E}+00$ & $1.00 \mathrm{E}+00$ & $0.00 \mathrm{E}+00$ & 9.96E-01 & $4.66 \mathrm{E}-01$ & $4.66 \mathrm{E}-01$ & $1.76 \mathrm{E}-01$ & $1.76 \mathrm{E}-01$ & $9.92 \mathrm{E}-01$ \\
\hline $\mathrm{CH} 3 \mathrm{OH}$ & $0.00 \mathrm{E}+00$ & $0.00 \mathrm{E}+00$ & $0.00 \mathrm{E}+00$ & $0.00 \mathrm{E}+00$ & $0.00 \mathrm{E}+00$ & $0.00 \mathrm{E}+00$ & $0.00 \mathrm{E}+00$ & $0.00 \mathrm{E}+00$ & $0.00 \mathrm{E}+00$ \\
\hline Stream & 8 & 9 & 10 & 11 & 12 & 13 & 14 & 15 & 16 \\
\hline Total Flow $\mathrm{mol} / \mathrm{min}$ & 131.13 & 890.55 & 1314.16 & 50.00 & 1264.12 & 1264.12 & 828.55 & 828.55 & 313.98 \\
\hline Temperature $\mathrm{C}$ & 35.00 & 35.00 & 30.58 & 30.58 & 30.58 & 200.00 & 200.00 & 35.00 & 35.00 \\
\hline Pressure bar & 1 & 1 & 1 & 1 & 1 & 45 & 40 & 40 & 40 \\
\hline $\mathrm{CH} 4$ & $3.17 \mathrm{E}-06$ & $2.00 \mathrm{E}-04$ & $4.42 \mathrm{E}-04$ & $0.00 \mathrm{E}+00$ & $4.59 \mathrm{E}-04$ & $4.59 \mathrm{E}-04$ & $7.01 \mathrm{E}-04$ & $7.01 \mathrm{E}-04$ & $4.45 \mathrm{E}-04$ \\
\hline $\mathrm{CO} 2$ & $7.44 \mathrm{E}-03$ & $9.64 \mathrm{E}-02$ & $2.03 \mathrm{E}-01$ & $0.00 \mathrm{E}+00$ & $2.11 \mathrm{E}-01$ & $2.11 \mathrm{E}-01$ & $3.20 \mathrm{E}-01$ & $3.20 \mathrm{E}-01$ & $2.71 \mathrm{E}-01$ \\
\hline $\mathrm{CO}$ & $6.65 \mathrm{E}-04$ & $2.89 \mathrm{E}-01$ & $2.69 \mathrm{E}-01$ & $0.00 \mathrm{E}+00$ & $2.79 \mathrm{E}-01$ & $2.79 \mathrm{E}-01$ & $1.65 \mathrm{E}-01$ & $1.65 \mathrm{E}-01$ & $2.01 \mathrm{E}-02$ \\
\hline $\mathrm{H} 2$ & $2.11 \mathrm{E}-09$ & $5.58 \mathrm{E}-01$ & $4.85 \mathrm{E}-01$ & $0.00 \mathrm{E}+00$ & $5.04 \mathrm{E}-01$ & $5.04 \mathrm{E}-01$ & $2.42 \mathrm{E}-01$ & $2.42 \mathrm{E}-01$ & $5.70 \mathrm{E}-08$ \\
\hline $\mathrm{H} 2 \mathrm{O}$ & 9.92E-01 & $5.61 \mathrm{E}-02$ & $3.80 \mathrm{E}-02$ & $1.00 \mathrm{E}+00$ & $0.00 \mathrm{E}+00$ & $0.00 \mathrm{E}+00$ & $2.06 \mathrm{E}-03$ & $2.06 \mathrm{E}-03$ & $5.41 \mathrm{E}-03$ \\
\hline $\mathrm{CH} 3 \mathrm{OH}$ & $0.00 \mathrm{E}+00$ & $0.00 \mathrm{E}+00$ & $5.05 \mathrm{E}-03$ & $0.00 \mathrm{E}+00$ & $5.25 \mathrm{E}-03$ & $5.25 \mathrm{E}-03$ & $2.71 \mathrm{E}-01$ & $2.71 \mathrm{E}-01$ & 7.03E-01 \\
\hline Stream & 17 & 18 & 19 & 20 & 21 & $\mathrm{MeOH}$ & PURGE & & \\
\hline Total Flow $\mathrm{mol} / \mathrm{min}$ & 514.57 & 605.15 & 423.61 & 313.98 & 90.58 & 223.40 & 181.55 & & \\
\hline Temperature $\mathrm{C}$ & 35.00 & 22.09 & 22.09 & 8.19 & 8.19 & 8.19 & 22.09 & & \\
\hline Pressure bar & 40 & 1 & 1 & 1 & 1 & 1 & 1 & & \\
\hline $\mathrm{CH} 4$ & $8.57 \mathrm{E}-04$ & $9.50 \mathrm{E}-04$ & $9.50 \mathrm{E}-04$ & $4.45 \mathrm{E}-04$ & $1.48 \mathrm{E}-03$ & $2.64 \mathrm{E}-05$ & $9.50 \mathrm{E}-04$ & & \\
\hline $\mathrm{CO} 2$ & $3.49 \mathrm{E}-01$ & $4.27 \mathrm{E}-01$ & $4.27 \mathrm{E}-01$ & $2.71 \mathrm{E}-01$ & $8.65 \mathrm{E}-01$ & $3.00 \mathrm{E}-02$ & $4.27 \mathrm{E}-01$ & & \\
\hline $\mathrm{CO}$ & $2.54 \mathrm{E}-01$ & $2.26 \mathrm{E}-01$ & $2.26 \mathrm{E}-01$ & $2.01 \mathrm{E}-02$ & $6.89 \mathrm{E}-02$ & $2.84 \mathrm{E}-04$ & $2.26 \mathrm{E}-01$ & & \\
\hline $\mathrm{H} 2$ & 3.89E-01 & $3.31 \mathrm{E}-01$ & $3.31 \mathrm{E}-01$ & $5.70 \mathrm{E}-08$ & $1.98 \mathrm{E}-07$ & $2.99 \mathrm{E}-16$ & $3.31 \mathrm{E}-01$ & & \\
\hline $\mathrm{H} 2 \mathrm{O}$ & $1.05 \mathrm{E}-05$ & $2.51 \mathrm{E}-05$ & $2.51 \mathrm{E}-05$ & $5.41 \mathrm{E}-03$ & $1.08 \mathrm{E}-04$ & $7.56 \mathrm{E}-03$ & $2.51 \mathrm{E}-05$ & & \\
\hline $\mathrm{CH} 3 \mathrm{OH}$ & $7.11 \mathrm{E}-03$ & $1.57 \mathrm{E}-02$ & $1.57 \mathrm{E}-02$ & $7.03 \mathrm{E}-01$ & $6.43 \mathrm{E}-02$ & $9.62 \mathrm{E}-01$ & $1.57 \mathrm{E}-02$ & & \\
\hline
\end{tabular}

\section{REFERENCES}

1. Foo D.C.Y. and Elyas R., Introduction to Process Simulation, in Chemical Engineering Process Simulation,3-21.(2017)

2. Bussche K.M.V. and Froment G.F., A Steady-State Kinetic Model for Methanol Synthesis and the Water Gas Shift Reaction on a Commercial Cu/ZnO/Al2O3Catalyst. JCat. 161 1-10.(1996)

3. Skrzypek J., Lachowska M., and Moroz H., Kinetics of methanol synthesis over commercial copper/zinc oxide/alumina catalysts. ChEnS. 46 2809-2813.(1991)

4. Snoeck J.W., Froment G.F., and Fowles M., Kinetic Study of the Carbon Filament Formation by Methane Cracking on a Nickel Catalyst. JCat. 169 250-262.(1997)

5. Benguerba Y., et al., Modelling of methane dry reforming over $\mathrm{Ni} / \mathrm{Al}_{2} \mathrm{O}_{3}$ catalyst in a fixed-bed catalytic reactor. Reaction Kinetics, Mechanisms and Catalysis. 114 109119.(2015)
6. Richardson J.T. and Paripatyadar S.A., Carbon dioxide reforming of methane with supported rhodium. Applied Catalysis. 61 293-309.(1990)

7. Hansen John B. and Højlund Nielsen Poul E., Methanol Synthesis.

8. Peter M., et al., Detailed kinetic modeling of methanol synthesis over a ternary copper catalyst. Chem. Eng. J. 203 480-491.(2012)

9. Šetinc M. and Levec J., On the kinetics of liquid-phase methanol synthesis over commercial $\mathrm{Cu} / \mathrm{ZnO} / \mathrm{Al}_{2} \mathrm{O}_{3}$ catalyst. ChEnS. 54 3577-3586.(1999)

10. Rujira J. K.K., et al., The effect of contaminated gases in syngas to biomethanol production. PACCON.(2018)

11. Rujira J. K.K., et al., Reforming of residue gas from $C B G$ process to synthetic gas for bio-methanol production. PACCON.(2018)

12. Graaf G.H., et al., Chemical equilibria in methanol synthesis. ChEnS. 41 2883-2890.(1986)

13. Graaf G.H., Stamhuis E.J., and Beenackers A.A.C.M., Kinetics of low-pressure methanol synthesis. ChEnS. 43 3185-3195.(1988) 